Zeszyty Naukowe Szkoły Głównej Gospodarstwa Wiejskiego w Warszawie

Problemy Rolnictwa Światowego tom 18 (XXXIII), zeszyt 3, 2018: 272-281

DOI: $10.22630 /$ PRS.2018.18.3.85

Tomasz Rokicki $^{1}$, Magdalena Golonko ${ }^{2}$, Aleksandra Perkowska ${ }^{3}$

Szkoła Główna Gospodarstwa Wiejskiego w Warszawie

\title{
Regionalizacja produkcji zwierzęcej na świecie
}

\section{Regionalization of Animal Production in the World}

\begin{abstract}
Synopsis. Celem głównym badań była ocena regionalizacji produkcji zwierzęcej na świecie oraz występującym w tym aspekcie zmian. W artykule przedstawiono wartość produkcji zwierzęcej w regionach świata określanych przez kontynenty. Źródłem materiałów były dane z FAOSTAT Okres badań dotyczył lat 2007-2016. Wartość światowej produkcji zwierzecej stale wzrastała. Jedynie w momencie kryzysu gospodarczego w 2009 roku oraz w latach 2014-2015 zaobserwowano spadki we wszystkich obszarach. Stwierdzono dużą koncentrację produkcji zwierzęcej, która była skupiona w Azji i Europie. Następowało stopniowe przenoszenie produkcji z Europy i Ameryki Północnej do Azji i Ameryki Południowej. Prawidłowości te zostały potwierdzone również przy analizie poszczególnych grup produktów zwierzecych, jak mieso, mleko i jaja. Jednocześnie stwierdzono bardzo dużą koncentrację i występowanie dużego zróżnicowania produkcji zwierzęcej w regionach. Dysproporcje wzrastały szybciej w przypadku produkcji jaj i mięsa niż mleka.
\end{abstract}

Słowa kluczowe: globalizacja, regionalizacja rolnictwa, produkcja zwierzęca na świecie

\begin{abstract}
The aim of the study was to assess the regionalization of animal production in the world and the changes that have occurred in this respect. The article presents the value of animal production in regions of the world defined by the continents. The source of the material was data from FAOSTAT. The period of research covered the years 2007-2016. The value of world animal production has steadily increased. Only at the time of the economic crisis in 2009 and in 2014-2015 were declines seen in all areas. There was a high concentration of animal production that was concentrated in Asia and Europe. There was a gradual relocation of production from Europe and North America to Asia and South America. These regularities have been confirmed also in the analysis of individual groups of animal products like meat, milk and eggs. At the same time, there was a very high concentration and a high degree of variation in animal production in the regions. Disproportions increased faster in meat and egg production than in milk production.
\end{abstract}

Key words: globalization, regionalization of agriculture, animal production in the world

JEL Classification: E00, Q10, Q13, Q18, R10

\section{Wprowadzenie}

Światowa gospodarka żywnościowa jest w coraz większym stopniu napędzana przez zmianę diety i wzorców konsumpcji żywności w stosunku do produktów zwierzęcych. W ostatnich dziesięcioleciach w rozwijających się krajach Azji, gdzie nastąpił znaczny

\footnotetext{
${ }^{1}$ dr hab. inż., Katedra Logistyki SGGW w Warszawie, ul Nowoursynowska 166, 02-787 Warszawa, e-mail: tomasz rokicki@sggw.pl, https://orcid.org/0000-0003-3356-2643

2 mgr, Katedra Logistyki SGGW w Warszawie, ul Nowoursynowska 166, 02-787 Warszawa, e-mail: magdalena_wiluk@sggw.pl,https://orcid.org/0000-0002-8532-6741

${ }^{3}$ mgr, Katedra Logistyki SGGW w Warszawie, ul Nowoursynowska 166, 02-787 Warszawa,

e-mail: aleksandra_perkowska@sggw.pl
} 
wzrost światowej populacji, konsumpcja mięsa i mleka rośnie. Na zagregowaną produkcje rolną wpływ ma nie tylko wzrost produkcji zwierzęcej, ale także powiązanie produkcji zwierzęcej z sektorem upraw, który dostarcza pasze, głównie zboża i rośliny oleiste. (World agriculture, 2006).

W ostatnich czterech dekadach nastapiła radykalna restrukturyzacja zakresu i charakteru produkcji i dystrybucji wielu towarów, w tym żywności (Galbraith, 2002). Proces ten został nazwany globalizacją, kształtując życie ludzi w sposób kulturowy, ideologiczny i ekonomiczny (Robinson i Carson, 2015).

Globalizacja jest zjawiskiem złożonym. Autorzy opisywali to pojęcie w różny sposób. Roland Robertson (1992) stwierdził, iż jest to „proces, poprzez który świat staje się w coraz większym stopniu jednym wspólnym miejscem (ang. single place)". Natomiast Antony Giddens (1994) definiował globalizację jako skomplikowany zbiór procesów, powodujący często powstawanie konfliktów, z powodu których tworzy się lokalny nacjonalizm, a także podkreślana jest lokalna tożsamości wiążąca się bezpośrednio z globalnymi oddziaływaniami.

Globalizacja została znacznie ułatwiona dzięki postępowi w natychmiastowym przepływie informacji przez Internet (Harvey 1999). Przepływy informacji odzwierciedlają procesy gospodarcze obejmujące powiązania i zależności wykraczające daleko poza lokalne, regionalne, a nawet krajowe otoczenie. Po części spowodowało to wzrost globalnych marek i produktów, które zasadniczo oferują jednolite doświadczenie wszędzie tam, gdzie są konsumowane. Ta wzajemna zależność pod względem dostępności i konsumpcji produktów jest częścią tendencji zmierzających do większej homogenizacji społecznej i kulturowej, chociaż efekt ten nie wyeliminował małych, prywatnych przedsiębiorców sprzedających wytworzone lokalnie towary w tym wyprodukowane lokalnie produkty spożywcze. (Jackson 2004). Globalizacja umożliwiła szybszy, niż w przeszłości, rozwój produkcji rolnej. Według danych FAOSTAT produkcja rolna wzrosła o prawie $25 \%$ od roku 2006 do 2016.

Tworzenie rynków globalnych jest głównym wynikiem procesów globalizacji w rolnictwie. Dobrze ilustruje to rosnący handel świeżymi owocami, świeżymi warzywami i kwiatami ciętymi. Rynek ten przekracza obecnie 5\% światowego handlu towarowego, porównywalnego $\mathrm{z}$ ropą naftową (Diop, Jaffee, 2005). Polityka i działalność supermarketów są kluczowe dla tego handlu, ponieważ oferowanie całorocznych dostaw świeżych produktów wymaga zaopatrzenia $\mathrm{z}$ różnych obszarów na całym świecie. Podkreśla to znaczenie zmieniającego się charakteru handlu detalicznego i wzorców konsumpcji w ramach procesu globalizacji (Coe i Wrigley, 2009).

Według Johna Mellora (2003) w miarę wzrostu eksportu wysokojakościowych produktów rolnych oraz wraz z rozwojem mnożników dochodu per capita, gwałtownie wzrośnie popyt krajowy na wysokiej jakości produkty zwierzęce i ogrodnictwo. W krajach o niskich dochodach około połowa przyrostów produkcji rolnej dotyczyć będzie wysokiej jakości ogrodnictwa i produktów zwierzęcych, zarówno w przypadku eksportu, jak i użytku domowego.

Globalizacja oraz regionalizacja są efektem internacjonalizacji gospodarki, która przyczynia się do kształtowania współczesnych międzynarodowych stosunków ekonomicznych (Żołądkiewicz, 2012). Region jest to pewien wydzielony, dosyć jednorodny obszar, który odróżnia się określonymi cechami od terenów do niego przyległych. Może zostać wyodrębniony na podstawie rozmaitych kryteriów zarówno geograficznych, jak i ekonomicznych, politycznych i kulturowych (Klecha-Tylec, 2013; 
Lubbe, 2010). Tradycyjnie region stanowił integralną część danego kraju. Obecnie termin ten stosowany jest $\mathrm{w}$ szerszym wymiarze jako obszar na pograniczu, np. tzw. euroregiony w UE bądź zbiór państw na danym obszarze geograficznym - kontynenty (Yip, 2004).

W latach 2007-2014 wartość światowej produkcji końcowej brutto rolnictwa zwiększyła się o $55 \%$. Występowała duża koncentracja produkcji rolniczej, skupiona w Azji i Europie. Następowało stopniowe przenoszenie się produkcji poszczególnych grup produktów rolnych, jak zboża i produkty zwierzęce z Europy i Ameryki Północnej do Azji i Ameryki Południowej. Na taką sytuację ma wpływ polityka rolna ograniczająca wzrost produkcji $\mathrm{w}$ UE, zaś liberalna $\mathrm{w}$ poszczególnych państwach azjatyckich i południowoamerykańskich. Naturalne warunki przyrodnicze oraz niski koszt produkcji są kolejnymi uwarunkowaniami, które preferują regiony Azji i Ameryki Południowej (Rokicki, Golonko, Perkowska, 2017).

Rynki rolne i polityka rolna $w$ krajach azjatyckich charakteryzują się dużą dynamiką przyrostu popytu na żywność. W ostatnich dwudziestu latach polityka rolna w krajach rozwijających się rozpoczęła przeobrażanie się, a $\mathrm{w}$ wielu $\mathrm{z}$ nich zaprzestano opodatkowywania rolników, rozpoczęto działania wspierające politykę producentów rolnych, poprzez instrumenty polityki handlowej, głównie cła. Proces ten jest szczególnie widoczny w azjatyckich gospodarkach transformacji, charakteryzujących się wysoką stopą wzrostu gospodarczego (Poczta-Wajda, Pawlak 2017).

\section{Materiał i metodyka badań}

Celem głównym badań była ocena stopnia regionalizacji produkcji zwierzęcej na świecie oraz występującym w tym aspekcie zmian. Celami szczegółowymi było przedstawienie stopnia koncentracji produkcji zwierzęcej, wskazanie regionów z dominującym udziałem tej produkcji na świecie, określenie kierunków i siły zmian w tym zakresie w poszczególnych obszarach świata. Do badań jako regiony przyjęto kontynenty. Źródła materiałów stanowią dane publikowane przez FAOSTAT. Okres badawczy obejmował lata 2007-2016. W pracy wykorzystano metodę porównawczą, posługiwano się wskaźnikami dynamiki, obliczono współczynnik koncentracji Giniego oraz przedstawiono stopień koncentracji za pomocą krzywej Lorenza. Do prezentacji wyników badań zastosowano metodę opisowa, tabelaryczna i graficzna.

\section{Wyniki badań}

W latach 2007-2014 wartość światowej zwierzęcej produkcji końcowej brutto zwiększyła się o 71\% z 987 mld USD do 1,4 bilionów USD. Do produktów zaliczonych do grupy produkcja zwierzęca zalicza się mięso i mleko pozyskiwane od różnych zwierząt, jajka, miód, wosk pszczeli, wełnę, kokony jedwabników. Jedynie w momencie wystąpienia kryzysu gospodarczego w 2009 roku oraz w latach 2014-2015 nastąił spadek wartości produkcji zwierzęcej (tab. 1). Jedną z przyczyn może być likwidacja kwot mlecznych w UE i związany z tym znaczny spadek cen surowca w 2015 roku. W poszczególnych regionach światach występowały podobne prawidłowości, z niewielkimi różnicami. W czasie kryzysu gospodarczego wartość produkcji zwierzęcej zmniejszyła się we wszystkich regionach. Najmocniej załamanie gospodarcze odcisnęło swoje piętno na produkcji zwierzęcej 
w Ameryce Północnej i Europie. W latach 2007-2016 podwoiła się wartość produkcji zwierzęcej w Ameryce Południowej, ale było to spowodowane bardzo dobrymi wynikami w 2008 roku, ale też w latach następujących po kryzysie gospodarczym. Duży wzrost odnotowano też w Azji (o 61\%) i Oceanii (o 41\%), zaś mniejszy w Ameryce Północnej (o 13\%). Z kolei wartość produkcji zwierzęcej spadła w Europie o $11 \%$ i w Afryce o $2 \%$. W przypadku Europy spowodowane to było obowiązującymi kwotami w odniesieniu do produkcji mleka oraz prowadzoną wspólną polityką rolną.

Tabela 1. Wskaźniki dynamiki o podstawie zmiennej dla wartości produkcji zwierzęcej na świecie w latach 2008$2016($ rok poprzedni $=100)$

Table 1. Changes in animal production value in the world in 2008-2016 (previous year $=100$ )

\begin{tabular}{c|ccccccccc}
\hline \multirow{2}{*}{ Regiony } & \multicolumn{7}{|c}{ Wskaźniki dynamiki łańcuchowe w latach $2008-2016$ (rok poprzedni=100) } \\
& 2008 & 2009 & 2010 & 2011 & 2012 & 2013 & 2014 & 2015 & 2016 \\
\hline Afryka & 120,78 & 96,06 & 106,38 & 108,40 & 95,08 & 100,73 & 101,55 & 85,80 & 88,06 \\
Ameryka Północna & 104,31 & 84,31 & 117,68 & 117,42 & 101,13 & 106,63 & 116,43 & 86,17 & 85,72 \\
Ameryka Południowa & 121,27 & 94,50 & 125,57 & 117,83 & 101,06 & 110,79 & 107,87 & 96,17 & 145,25 \\
Azja & 115,59 & 99,11 & 114,26 & 123,38 & 103,13 & 102,40 & 90,36 & 99,55 & 104,69 \\
Europa & 119,22 & 84,49 & 104,22 & 114,98 & 98,76 & 105,48 & 98,25 & 77,29 & 93,28 \\
Oceania & 114,76 & 85,71 & 118,88 & 131,18 & 99,57 & 90,94 & 108,97 & 71,20 & 98,22 \\
Świat & 115,47 & 92,52 & 112,92 & 119,31 & 101,28 & 104,16 & 98,14 & 91,24 & 103,87 \\
\hline
\end{tabular}

Źródło: opracowanie własne na podstawie danych FAOSTAT.

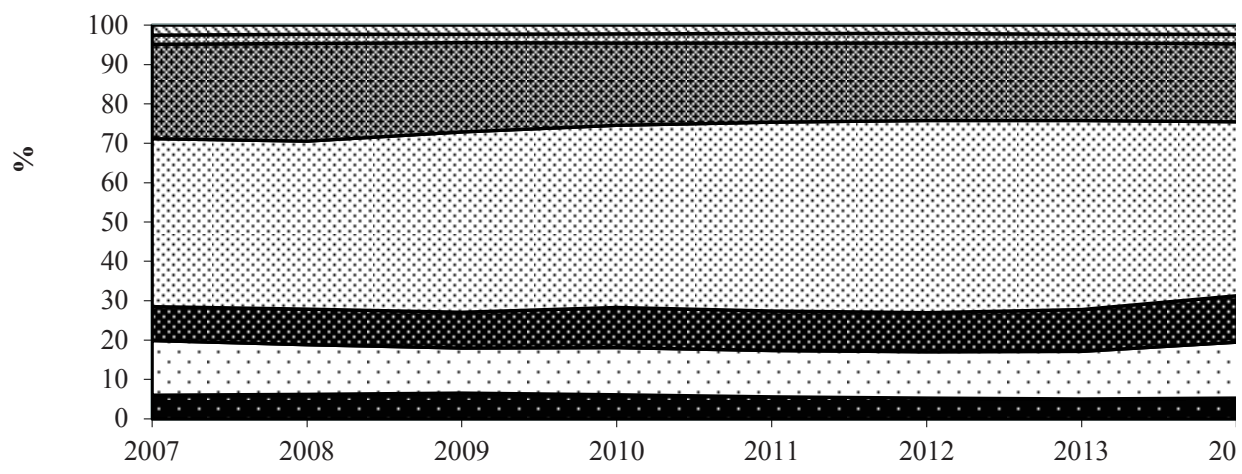

Rys. 1. Udział regionów świata w produkcji zwierzęcej w latach 2007-2016 (\%)

Fig. 1. Share of world regions in animal production in 2007-2016 (\%)

Źródło: jak w tab. 1.

Oprócz tempa zmian ważny jest udział poszczególnych regionów (kontynentów). Zdecydowanie największa była wartość produkcji zwierzęcej wytwarzanej w Azji, która wyniosła 42,7\% w 2007 roku i wzrosła do 48,6\% w 2016 roku (rys. 1). Na kolejnym miejscu znajdowała się Europa, której udział jednak systematycznie spadał z 24,0 do 15,1\% w latach 2007-2014. Spadek następował też w Ameryce Północnej z 14,0 do 11,1\%. Z kolei 
znaczenie produkcji zwierzęcej Ameryki Południowej zwiększało się, o czym świadczy wzrost jej udziału w światowej produkcji z 8,5\% w 2007 roku do 17,2\% w 2016 roku. Następowało więc stopniowe przenoszenie produkcji zwierzęcej do miejsc posiadających korzystniejsze warunki przyrodniczych i o niższych kosztach produkcji. Oczywiście przy tego typu porównaniach należy pamiętać o różnych potencjałach poszczególnych kontynentów, głównie w areale powierzchni użytków rolnych.

Do określenia stopnia koncentracji produkcji zwierzęcej na świecie zastosowano współczynnik Giniego. Dane dotyczyły roku 2016, zaś liczba obserwacji wynosiła 7. Współczynnik Giniego obliczony z próby wyniósł 0,47, zaś estymowany współczynnik dla populacji 0,57. Oznacza to bardzo dużą koncentrację produkcji zwierzęcej i zróżnicowanie występujące na świecie. Dodatkowo to zróżnicowanie przedstawia krzywa koncentracji Lorenza (rys. 2). W 2007 roku współczynniki Giniego były niższe, bo odpowiednio $0,45 \mathrm{z}$ próby i 0,54 estymowany dla populacji. Oznacza to, że postępują procesy koncentracji produkcji zwierzęcej. Występował jeden region (Azja), który wytwarzał około $49 \%$ światowej produkcji zwierzęcej. Z kolei w Oceanii było to mniej niż $2 \%$, podobnie w Ameryce Środkowej. Koncentracja produkcji zwierzęcej będzie następowała dalej, głównie za sprawą różnych regulacji i polityk rolnych stosowanych na poszczególnych kontynentach i w indywidualnych państwach.

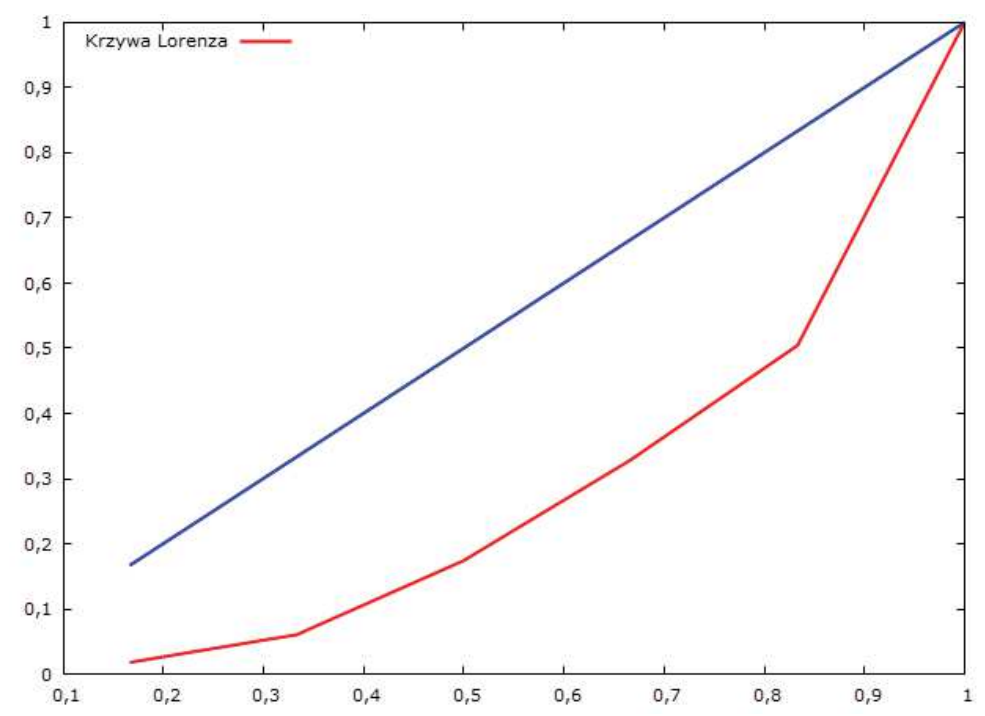

Rys. 2. Krzywa koncentracji Lorenza dla wartości produkcji zwierzęcej w regionach świata w latach 2007-2016

Fig. 2. Lorenz concentration curve for the value of animal production in the regions of the world in the years $2007-$ 2016

Źródło: jak w tab. 1.

Poszczególne kontynenty, ale też i kraje, specjalizują się w chowie i hodowli określonych gatunków zwierząt. Decydujące znaczenie mają warunki przyrodnicze. Wśród produktów zwierzęcych do najważniejszych grup należą mięso, mleko i jajka. Na poszczególnych kontynentach są utrzymywane różne gatunki i rasy zwierząt. Mięso było pozyskiwane od zwierząt gospodarskich, jak krowy, owce, kozy, świnie, kaczki, gęsi, 
indyki, kurczaki, konie, muły, ale też od bawołów, wielbłądów i wielbłądowatych, gryzoni, zwierząt dziko żyjących, dzikiego ptactwa. Łączna wartość produkcji mięsa wzrosła w latach $2007-2016$ o $45 \%$ z 598 do 868 mld USD. Wzrost był podobny z występującym w odniesieniu do całej produkcji zwierzęcej. Podwojenie wartości produkcji mięsa nastapiło w Ameryce Południowej (wzrost o 120\%). Duży wzrost odnotowano tez w Azji (o 73\%), zaś mniejszy w Ameryce Północnej (o 21\%). Z kolei spadek produkcji wystapił w Europie (o 8\%) i w Afryce (o 5\%). W Oceanii odnotowano bardzo mały wzrost, bo o 1\%. Duże znaczenie $\mathrm{w}$ tej produkcji mają uregulowania i polityka rolna, ale też wystąpienie korzystnych lub niekorzystnych warunków do chowu i hodowli zwierząt w poszczególnych latach. Najbardziej kryzysowy był 2009 roku, gdy spadki produkcji nastapiły na wszystkich kontynentach. Takie spadki były konsekwencją kryzysu gospodarczego. Niekorzystne były również lata 2014-2015. Wówczas dominowały spadki i jedynie w pojedynczych regionach wzrosła wartość produkcji zwierzęcej.

Tabela 2. Wskaźniki dynamiki o podstawie zmiennej dla wartości produkcji mięsa na świecie w latach 2008-2016 $($ rok poprzedni $=100)$

Table 2. Changes in meat production value in the world in 2008-2016 (previous year $=100)$

\begin{tabular}{l|ccccccccc}
\hline \multirow{2}{*}{ Regiony } & \multicolumn{7}{c}{ Łańcuchowe wskaźniki dynamiki w latach $2008-2016$ (rok poprzedni=100) } \\
& 2008 & 2009 & 2010 & 2011 & 2012 & 2013 & 2014 & 2015 & 2016 \\
\hline Afryka & 120,48 & 93,91 & 108,60 & 88,21 & 96,18 & 101,85 & 98,36 & 105,61 & 86,10 \\
Ameryka Północna & 105,02 & 89,73 & 117,05 & 113,99 & 103,42 & 106,16 & 115,44 & 88,59 & 86,02 \\
Ameryka Południowa & 117,81 & 94,67 & 125,41 & 117,05 & 101,31 & 111,27 & 108,33 & 99,82 & 110,42 \\
Azja & 122,41 & 97,33 & 115,81 & 125,90 & 103,40 & 101,45 & 88,09 & 101,01 & 106,98 \\
Europa & 118,85 & 90,22 & 101,16 & 114,49 & 102,03 & 102,18 & 94,99 & 80,12 & 93,09 \\
Oceania & 98,84 & 98,48 & 107,52 & 62,25 & 100,94 & 180,15 & 93,66 & 89,51 & 101,89 \\
Świat & 119,27 & 93,92 & 112,67 & 120,50 & 102,79 & 104,81 & 95,10 & 93,94 & 99,15 \\
\hline
\end{tabular}

Źródło: opracowanie własne na podstawie danych FAOSTAT.

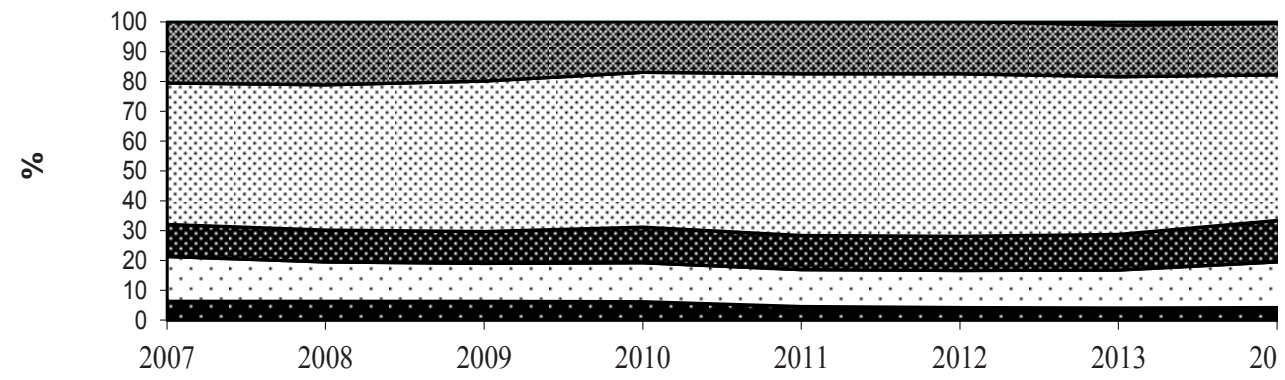

Rys. 3. Udział regionów świata w produkcji mięsa w latach 2007-2016 (\%)

Fig. 3. Share of world regions in meat production in 2007-2016 (\%)

Źródło: jak w tab. 1 .

W przypadku produkcji zwierzęcej następowało zjawisko koncentracji produkcji w Azji, gdyż udział tego regionu w światowej produkcji wzrósł w latach 2007-2016 z 47,4 
do $56,7 \%$ (rys. 3). Szczególnie duże zmiany w strukturze produkcji zwierzęcej były widoczne w latach 2009, 2011 i 2015-2016. Zmniejszało się systematycznie znaczenie Ameryki Północnej (z 15,0 do 12,5\% w latach 2007-2016) i Europy (z 21,9 do 13,9\%). Udział Afryki i Oceanii w produkcji zwierzęcej był stabilny. W Ameryce Południowej odnotowano największą dynamikę wzrostu produkcji zwierzęcej, w rezultacie udział tego regionu w światowej produkcji wzrósł do 16,3\% w 2016 roku.

Tabela 3. Wskaźniki dynamiki o podstawie zmiennej dla wartości produkcji mleka na świecie w latach 2008-2016 $($ rok poprzedni $=100)$

Table 3. Changes in milk production value in the world in 2008-2016 (previous year $=100$ )

\begin{tabular}{l|ccccccccc}
\hline \multirow{2}{*}{ Regiony } & \multicolumn{6}{c}{ Wskaźniki dynamiki łańcuchowe w latach 2008-2016 (rok poprzedni=100) } \\
& 2008 & 2009 & 2010 & 2011 & 2012 & 2013 & 2014 & 2015 & 2016 \\
\hline Afryka & 121,95 & 103,43 & 102,17 & 108,16 & 87,82 & 99,42 & 107,92 & 84,99 & 93,60 \\
Ameryka Północna & 98,78 & 73,19 & 125,99 & 123,61 & 94,64 & 106,87 & 119,20 & 72,32 & 96,70 \\
Ameryka Południowa & 133,37 & 91,23 & 129,90 & 114,09 & 98,24 & 107,59 & 105,66 & 83,94 & 136,67 \\
Azja & 89,96 & 103,50 & 122,00 & 111,31 & 103,27 & 93,01 & 106,41 & 100,74 & 99,06 \\
Europa & 120,07 & 74,64 & 111,48 & 116,54 & 91,23 & 113,55 & 104,07 & 71,57 & 94,30 \\
Oceania & 151,87 & 70,66 & 126,98 & 136,00 & 94,92 & 95,61 & 133,65 & 54,79 & 88,38 \\
Świat & 106,57 & 87,29 & 118,12 & 114,85 & 97,08 & 102,08 & 108,11 & 84,05 & 99,80 \\
\hline
\end{tabular}

Źródło: opracowanie własne na podstawie danych FAOSTAT.

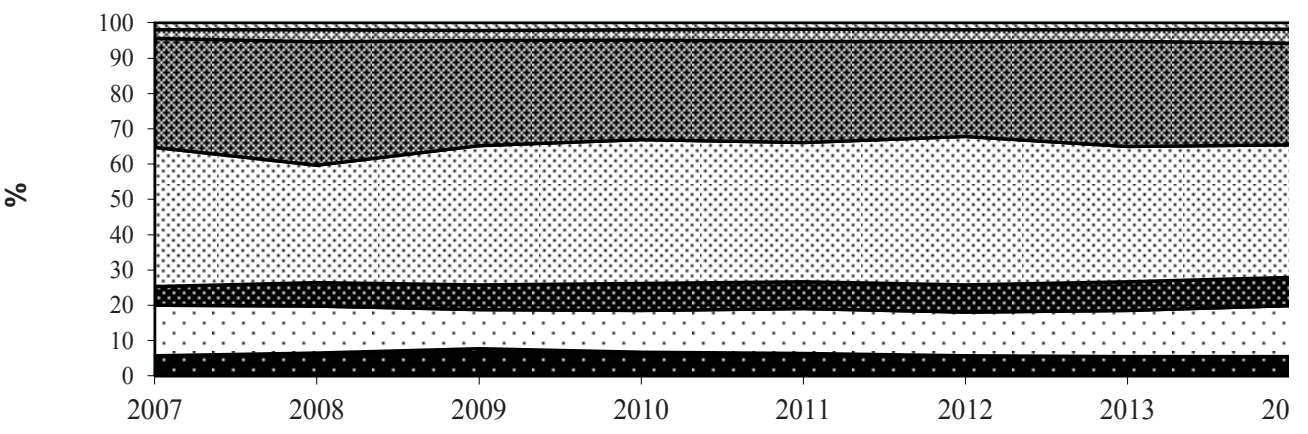

Rys. 4 Udział regionów świata w produkcji mleka w latach 2007-2016 (\%)

Fig. 4 Share of world regions in milk production in 2007-2016 (\%)

Źródło: jak w tab. 1.

Kolejnym ważnym produktem pochodzenia zwierzęcego jest mleko, które pochodzi głownie od krów, ale też kóz, owiec, wielbłądów i bawołów. Wartość produkcji mleka na świecie zwiększyła się w latach 2007-2016 o 13,4\% z 287 do 325 mld USD. Produkcja ta podwoiła się w Ameryce Południowej (wzrost o 131\%), zaś mniejszy wzrost nastąpił w Azji (o 29\%), Oceanii (o 9\%) i Afryce (o 4\%). Wartość produkcji mleka zmniejszyła się najwięcej w Europie, bo o 15\%, zaś w mniejszym zakresie w Ameryce Północnej (o 5\%). Podobnie, jak dla produkcji mięsa, największe spadki wartości produkcji mleka wystapiły w 2009 roku (tab. 3). Jedynie w Azji i Afryce odnotowano wzrost po 3,5\%. Kolejne trudności były w latach 2012 i 2015-2016, gdy jedynie w Azji odnotowano wzrost. 
Szczególnie korzystne dla produkcji mleka były lata 2010-2011 i 2014. W przypadku produkcji mleka na jej wartość oprócz czynników rynkowych wpływają również uwarunkowania produkcyjne, jak np. dostępność pasz w danym roku.

Tabela 4. Wskaźniki dynamiki o podstawie zmiennej dla wartości produkcji jaj na świecie w latach 2008-2016 $($ rok poprzedni $=100)$

Table 4. Changes in eggs production value in the world in 2008-2016 (previous year $=100$ )

\begin{tabular}{l|ccccccccc}
\hline \multirow{2}{*}{ Regiony } & \multicolumn{7}{c}{ Wskaźniki dynamiki łańcuchowe w latach $2008-2016$ (rok poprzedni=100) } \\
& 2008 & 2009 & 2010 & 2011 & 2012 & 2013 & 2014 & 2015 & 2016 \\
\hline Afryka & 121,86 & 87,47 & 107,01 & 112,77 & 107,70 & 97,37 & 109,86 & 83,66 & 81,53 \\
Ameryka Północna & 126,18 & 77,09 & 89,16 & 136,18 & 105,48 & 111,81 & 115,71 & 123,21 & 51,41 \\
Ameryka Południowa & 132,23 & 105,22 & 113,37 & 144,04 & 108,52 & 122,82 & 111,40 & 82,88 & 374,44 \\
Azja & 117,61 & 102,63 & 102,09 & 126,76 & 98,00 & 105,46 & 87,99 & 91,69 & 114,30 \\
Europa & 117,60 & 92,96 & 94,14 & 109,24 & 113,75 & 93,30 & 96,44 & 85,58 & 90,25 \\
Oceania & 115,83 & 92,44 & 115,16 & 145,96 & 101,76 & 106,23 & 92,61 & 83,79 & 130,29 \\
Świat & 119,24 & 97,89 & 100,95 & 124,65 & 101,90 & 105,12 & 93,96 & 92,62 & 124,90 \\
\hline
\end{tabular}

Źródło: opracowanie własne na podstawie danych FAOSTAT.

Produkcja mleka była skoncentrowana w Azji, jednak przewaga tego regionu nie była już tak duża (rys. 4). Udział Azji w światowej produkcji mleka w 2016 wyniósł około 45\%. Duże znaczenie miała też Europa, w której wytworzono 23\% tej produkcji (w 2007 roku było to $31 \%$ ). Po ponad $10 \%$ udział przypadł na Ameryki Północną i Południową. W przypadku produkcji mleka zmniejszał się udział Europy i Ameryki Północnej, zaś zwiększał Azji i Ameryki Południowej, które miały dobre warunki do produkcji zwierzęcej. Zmiany te były dosyć szybkie.

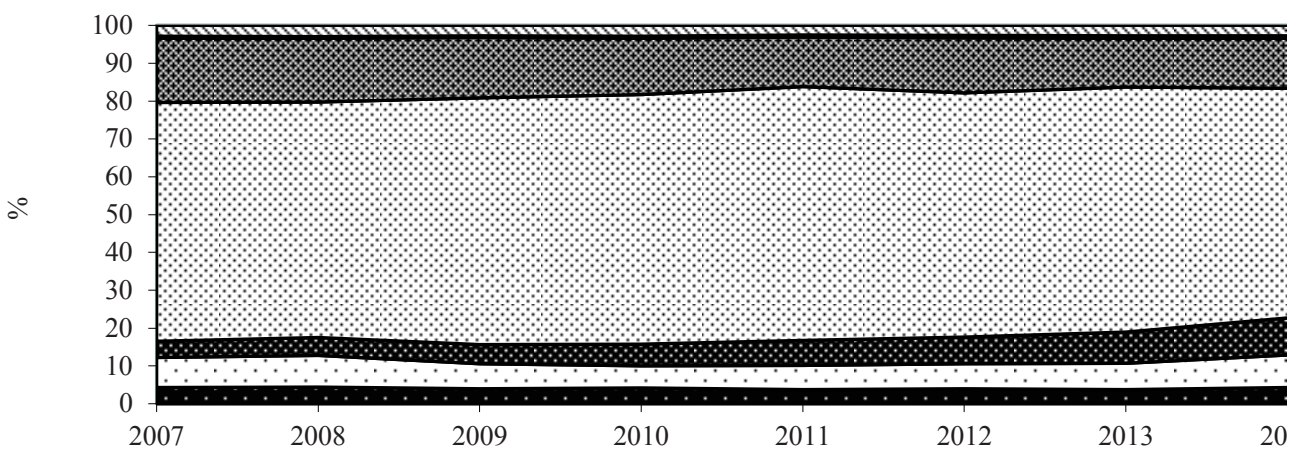

Rys. 5. Udział regionów świata w produkcji jaj w latach 2007-2016 (\%)

Fig. 5. Share of world regions in eggs production in 2007-2016 (\%)

Źródło: jak w tab. 1.

Ostatnią znaczącą grupą produktów pozyskiwanych od zwierząt były jaja. Były to głownie jaja kur, ale też innych ptaków. Wartość produkcji jaj wzrosła na świecie w latach $2007-2016$ o $71 \%$ z 90 do 153 mld USD. Było to tempo wyższe niż innych produktów zwierzęcych. Gigantyczny wzrost odnotowano w Ameryce Południowej (o 946\%), głównie 
przez duży przyrost w 2016 roku. Duży wzrost był też w Oceanii (o 97\%), a w dalszej kolejności Azji (49\%) i Afryce (41\%). Z kolei najniższy wzrost wartości produkcji jaj był w Ameryce Północnej (o 2\%) i w Afryce (1\%). Jedynie w Europie zanotowano spadek, który wyniósł 11\%. Kryzys gospodarczy w 2009 roku wpłynął na wartość tej produkcji, ale występowały też równie niekorzystne lata, jak 2014-2015 (tab. 4). Najkorzystniejszy był 2011 rok, gdy odnotowano wzrosty we wszystkich regionach. Duży wpływ na osiagane wyniki miały różnego rodzaju problemy związane z chorobami, higieną. Produkcja była rozwijana w krajach charakteryzujących się niskimi kosztami, w tym tanimi paszami, często produkowanymi z modyfikowanych genetycznie ziaren. Przykładem takiego kraju może być Brazylia.

W produkcji jaj występowała największa koncentracja produkcji, spośród wszystkich omawianych podstawowych grup produktów pochodzenia zwierzęcego. W Azji wytwarzano bowiem w 2011 roku nawet 67\% tych produktów. W 2016 roku udział zmniejszył się do 55\%, głównie na skutek zwiększonej produkcji w Ameryce Południowej. W 2016 roku właśnie Ameryka Południowa zajmowała drugie miejsce (26\%), kolejne były Europa (9\%), Ameryka Północna (5\%) i Afryka (3\%). W latach 2007-2016 zwiększył się udział w strukturze tylko w przypadku Ameryki Południowej, która intensywnie rozwijała tę produkcję.

\section{Podsumowanie}

W opracowaniu ukazano zmiany wartości produkcji zwierzęcej w regionach świata. Na poziomie makro można zaobserwować pewne prawidłowości. Wartość światowej produkcji zwierzęcej stale wzrastała. Jedynie w momencie kryzysu gospodarczego w 2009 roku oraz w latach 2014-15 zaobserwowano spadki we wszystkich obszarach poza pojedynczymi przypadkami. Zauważono, że występowała duża koncentracja produkcji zwierzęcej, która była skupiona w Azji i Europie. Następowało stopniowe przenoszenie produkcji z Europy i Ameryki Północnej do Azji i Ameryki Południowej. Koncentracja nasilała się. Prawidłowości te zostały potwierdzone również przy analizie poszczególnych grup produktów pochodzenia zwierzęcego, jak mięso, mleko i jaja. Jednocześnie stwierdzono bardzo dużą koncentrację i występowanie dużego zróżnicowania produkcji zwierzęcej w regionach, o czym świadczy obliczony współczynniki Giniego oraz krzywa koncentracji Lorenza.

Przeprowadzona analiza wskazuje, że dysproporcje w produkcji zwierzęcej wzrastały szybciej w przypadku mięsa i jaj niż mleka Na taką sytuację miała wpływ polityka rolna, która np. ograniczała wzrost produkcji w UE, zaś była liberalna w poszczególnych państwach azjatyckich i południowoamerykańskich. Dodatkowo sprzyjające naturalne warunki przyrodnicze i niski koszt produkcji były i pozostają kolejnymi czynnikami, które preferowały regiony Azji i Ameryki Południowej oraz Oceanii. W przypadku tego ostatniego regionu skala działalności była jednak zbyt mała, aby był on znaczącym obszarem w światowej produkcji rolniczej.

Ciągle dominującym surowcem pozyskiwanym od zwierząt pozostawało mięsa, mniejsze znaczenie miały mleko i jaja. Tempo zmian wartości produkcji mięsa było podobne, jak produktów zwierzęcych ogółem. Najszybciej w ujęciu wartościowym wzrastała produkcja jaj, zaś najwolniej mleka. 
Procesy globalizacji dotyczą również rolnictwa. Powodują one, że produkcja zwierzęca jest stopniowo przenoszona do regionów charakteryzujących się najlepszymi warunkami naturalnymi i niskimi kosztami produkcji. Wśród analizowanych regionów (kontynentów) występuje duże zróżnicowanie między krajami. Analizy dotyczące zależności międzynarodowych mogą być więc przedmiotem pogłębionych badań. W regionie Azja są kraje, gdzie odnotowywano duży wzrost produkcji zwierzęcej, jak np. Chiny, ale też obszary ze spadkiem tej produkcji.

\section{Literatura}

Dane z FAOSTAT (2018). Pobrano w lipcu 2018 z: http://www.fao.org.

Diop, N., Jaffee, S.M. (2005). Fruits and vegetables: global trade and competition in fresh and processed product markets. W: Global Agricultural Trade and Developing Countries (red. A. Aksoy, J. Beghin), World Bank, Waszyngton, 237-257.

Galbraith, K. (2002). Globalisation: Making Sense of an Integrating World. Bloomberg Press, Londyn.

Giddens, A. (1994). Beyond Left and Right. The Future of Radical Politics. Stanford University Press, Stanford.

Harvey, D.W. (1999). Time-space compression and the post-modern condition. W: Modernity: Critical Concepts (red. M. Waters). Londyn, 98-118.

Jackson, P. (2004). Local consumption cultures in a globalizing world. Transactions of the Institute of British Geographers, 29(2), 165-178.

Klecha-Tylec, K. (2013). Regionalizm w teorii i praktyce państw Azji Wschodniej (Regionalism in the theory and practice of East Asian countries). Wyd. Naukowe PWN Warszawa.

Lubbe, A. (2010). Globalizacja i regionalizacja we współczesnej gospodarce światowej (Globalization and regionalization in the modern global economy). W: Rozwój w dobie globalizacji (red. A. Bąkiewicz, U. Żuławska). Polskie Wyd. Ekonomiczne, Warszawa.

Mellor, J. (2003). Trade Reforms and Food Security: Conceptualizing the Linkages. Food and Agriculture Organization of the United Nations.

Poczta-Wajda, A., Pawlak, K. (2017). Globalne skutki ewolucji polityki handlowej na rynkach rolnych w rozwijajacych sie krajach azjatyckich (The Global Impact of the Evolution of Trade Policy on Agricultural Markets in Developing Asian Countries). Roczniki Naukowe SERiA, 19(3), 231-237.

Robertson, R. (1992). Globalization: Social Theory and Global Culture. Sage Publications, Londyn.

Robinson, G.M., Carson D.A. (2015). Handbook on the Globalisation of Agriculture. Edward Elgar Pub.

Rokicki, T., Golonko, M., Perkowska, A. (2017). Regionalizacja rolnictwa na świecie (Regionalization of Agriculture around the World). Zeszyty Naukowe SGGW Problemy Rolnictwa Światowego, 17(3), 239-248.

Staszczak, D. (2008). Znaczenie regionalizacji i globalizacji dla konkurencyjności polskich przedsiębiorstw agrobiznesu (Importance of Regionalization and Globalization for the Competitiveness of the Polish Agribusiness Enterprises). Roczniki Naukowe SERiA, 10(2), 246-250.

World agriculture: towards 2030/2050 Interim report (2006). Global Perspective Studies Unit Food and Agriculture Organization of the United Nations, Rzym.

Yip, G.S. (2004). Strategia globalna (Global strategy). Polskie Wyd. Ekonomiczne, Warszawa.

Żołądkiewicz, K. (2012). Regionalizacja i regionalizm w gospodarce światowej (Regionalization and regionalism in the global economy). W: Globalizacja i regionalizacja w gospodarce światowej (red. R. Orłowska, K. Żołądkiewicz). Polskie Wyd. Ekonomiczne, Warszawa.

Do cytowania / For citation:

Rokicki T., Golonko M., Perkowska A. (2018). Regionalizacja produkcji zwierzęcej na świecie. Problemy Rolnictwa Światowego, 18(3), 272-281; DOI: 10.22630/PRS.2018.18.3.85

Rokicki T., Golonko M., Perkowska A. (2018). Regionalization of Animal Production in the World (in Polish). Problems of World Agriculture, 18(3), 272-281; DOI: 10.22630/PRS.2018.18.3.85 